\title{
Optimization of DNA delivery by three classes of hybrid nanoparticle/DNA complexes
}

\author{
Qiu Zhong ${ }^{1 *}$, Dakshina Murthy Devanga Chinta ${ }^{2}$, Sarala Pamujula ${ }^{2}$, Haifan Wang ${ }^{1,3}$, Xin Yao ${ }^{1}$, Tarun K Mandal ${ }^{2}$, \\ Ronald B Luftig ${ }^{1 *}$
}

\begin{abstract}
Plasmid DNA encoding a luciferase reporter gene was complexed with each of six different hybrid nanoparticles (NPs) synthesized from mixtures of poly ( $\mathrm{D}$, L-lactide-co-glycolide acid) (PLGA 50:50) and the cationic lipids DOTAP (1, 2-Dioleoyl-3-Trimethyammonium-Propane) or DC-Chol \{3ß-[N-(N', N'-Dimethylaminoethane)-carbamyl] Cholesterol\}. Particles were 100-400 nm in diameter and the resulting complexes had DNA adsorbed on the surface (out), encapsulated (in), or DNA adsorbed and encapsulated (both). A luciferase reporter assay was used to quantify DNA expression in 293 cells for the uptake of six different NP/DNA complexes. Optimal DNA delivery occurred for $10^{5}$ cells over a range of $500 \mathrm{ng}-10 \mu \mathrm{g}$ of NPs containing 20-30 $\mathrm{mg}$ DNA per $1 \mathrm{mg}$ of NPs. Uptake of DNA from NP/ DNA complexes was found to be 500-600 times as efficient as unbound DNA. Regression analysis was performed and lines were drawn for DNA uptake over a four week interval. NP/DNA complexes with adsorbed NPs (out) showed a large initial uptake followed by a steep slope of DNA decline and large angle of declination; lines from uptake of adsorbed and encapsulated NPs (both) also exhibited a large initial uptake but was followed by a gradual slope of DNA decline and small angle of declination, indicating longer times of luciferase expression in 293 cells. NPs with encapsulated DNA only (in), gave an intermediate activity. The latter two effects were best seen with DOTAP-NPs while the former was best seen with DC-Chol-NPs. These results provide optimal conditions for using different hybrid NP/DNA complexes in vitro and in the future, will be tested in vivo.
\end{abstract}

\section{Introduction}

The purpose of this study is to develop a new biodegradable non-viral vector system for the effective transfer of genes to cells and animals. Viral vectors that have been utilized with positive results are adenoviruses with an extremely high transduction efficiency, and adenoassociated viruses (AAV) which are nonpathogenic. Lentivirus (LV) and retrovirus (RV) vectors have also been developed because they can be stably integrated leading to a long lasting genetic transfer. All four approaches are non-toxic and have dominated viral gene therapy efforts in clinical trials and animal models [1-6]. However, after the adverse events which occurred in clinical trials using an RV vector that induced a lymphoproliferative disorder in 2002-2003 [7] due to insertional mutagenesis [8-10], concerns were raised about gene transfer with such a vector. An adenovirus vector also

\footnotetext{
* Correspondence: qzhong@lsuhsc.edu; rlufti@lsuhsc.edu

'Department of Microbiology Immunology and Parasitology, Louisiana State University Health Sciences Center, New Orleans, Louisiana 70112, USA
}

lead to a patient's death in 1999 due to an adverse host immunogenic reaction [11] and AAV vectors still possess an unknown risk with regard to long-term adverse effects [12-14]. Further, viral vectors have their limitations in transfections due to low transgene size; they are expensive to produce and further in many applications they are limited to transient expression $[12,13,15,16]$. Thus efforts have been directed to develop non-viral gene delivery systems, which include liposome nanoparticles $[17,18]$, the "ballistic" gene gun $[19,20]$, electroporation [21-23] and cationic lipid complexes with DNA [24-28] in vitro and in vivo. However all of these have been beset with issues of cytotoxicity, stability in serum or tissues and like viral vectors, in the duration of gene expression $[29,30]$. More recent efforts using poly-ethyleneimine (PEI) multilayered materials containing DNA assemblies, as well as blending poly-orthoester (POE) microspheres with branched PEI have been promising as DNA transfection platforms for targeting phagocytic cells [31]. Still, particle size and safety issues with animals remain potential problems with these approaches. 
Thus, there is a need to establish a biodegradable, stable and long lived nanoparticle vector delivery system. We have established such a system. These are hybrid nanoparticles (NPs) manufactured using the solvent evaporation method [32]. The 100-400 $\mathrm{nm}$ particles are derived from a poly (D, L-lactide-co-glycolide acid) (PLGA 50:50) base with added cationic lipids (DOTAP or DC$\mathrm{Chol}$ ) in organic solution and protamine sulphate in the aqueous solution for enhanced DNA binding ability and increased zeta potential on the NP surface [33]. Using this procedure, molecules for gene therapy (plasmid DNA, antisense oligonucleotide, small interfering RNA) can be adsorbed on the surface or encapsulated into the NPs. An advantage of this method is that the simple evaporation process is performed under mild physicochemical conditions and leads to improved nucleic acid absorption. This method requires dissolving both polymers and lipids in non-aqueous phase and nucleic acid in the aqueous phase.

In previous studies, we have used agarose gel electrophoresis to demonstrate that plasmid DNA can be bound and released from cationic microparticles $[34,35]$. Here we improve upon these studies by using the luciferase gene as a sensitive marker for DNA activity in transfected cells. Overall, three classes of DNA adsorbed and/or encapsulated hybrid NPs were formulated; they were designated as DNA adsorbed (out), DNA encapsulated (in), and DNA adsorbed/encapsulated (both) NPs. The release profile of DNA from PLGA/DOTAP or PLGA/ DC-Chol adsorbed NPs (out) after transfection with 293 cells exhibited a large initial uptake followed by a rapid DNA decline over a four week period. This was based on the measurement of luciferase activity in 293 cells at 3-4 day intervals. The encapsulated (in) and adsorbed/encapsulated (both) NPs also showed an initial uptake, but was followed by a period of gradual DNA degradation seen by a sustained and a slow release of encapsulated DNA in the 239 cells. Hybrid NPs as constituted should provide an effective alternative to viral gene therapy. Recent applications of similar PLGA/DOTAP NP technology, using an asialofetuin ligand complexed with the therapeutic gene IL-12 look promising in this regard [36].

\section{Methods \\ Materials}

1, 2-Dioleoyl-3-Trimethylammonium-Propane (Chloride Salt) (DOTAP) and $3 \beta-\left[\mathrm{N}-\left(\mathrm{N}^{\prime}, \mathrm{N}^{\prime}\right.\right.$-Dimethylaminoethane)-carbamoyl] cholesterol hydrochloride (DC-Chol) were purchased from Avanti Polar Lipid (Alabaster, AL). The copolymer poly (D, L-lactic-co-glycolic acid), PLGA 50:50 (RG 502; inherent viscosity $0.2 \mathrm{dL} / \mathrm{g}$ ) was obtained from Boehringer Ingelheim (Germany) and Protamine Sulphate (PS) was from Sigma (St. Louis, MO). The reporter plasmid DNA
pGL4.75 (pLuc) containing the Renilla luciferase gene and Luciferase assay kit were purchased from Promega (Madison, MI). Lipofectamine ${ }^{\mathrm{ma}} 2000$ (Lip2000) was obtained from Invitrogen (Carisbad, CA).

\section{Cell Culture}

Adherent 293 and PC-3 human prostate tumor cells were from ATCC (Manassas, VA) and maintained at $37^{\circ}$ $\mathrm{C}$ in $5 \% \mathrm{CO}_{2}$ in Dulbecco's modified Eagle's medium (DMEM) supplemented with $10 \%(\mathrm{v} / \mathrm{v})$ heat-inactivated fetal bovine serum (FBS) and $1 \%(\mathrm{v} / \mathrm{v})$ penicillin $(5,000$ $\mathrm{U} / \mathrm{ml})$, and streptomycin $(5,000 \mu \mathrm{g} / \mathrm{ml})$ from Invitrogen (Carisbad, CA). The adherent LNcap human prostate tumor cells and the non-adherent suspension MOLT-4 human T lymphoblast cell line from ATCC were maintained in RPMI-1640 Medium supplemented with serum and antibiotics, as above. All cells were passaged 1:4 twice a week.

\section{Preparation of PLGA/DOTAP or PLGA/DC-Chol Hybrid Nanoparticles}

PLGA is an FDA approved biodegradable polymer [37]. The PLGA-Lipid hybrid NPs with and/or without DNA were formulated by using a double emulsion $(\mathrm{W} / \mathrm{O} / \mathrm{W})$ solvent evaporation method (Figure 1). Briefly, the first or aqueous solution (Solution I) Tris-EDTA buffer ( $\mathrm{pH}$ 8.0) was mixed with PS plus DNA for future inside (in) or both NPs or PS minus DNA for future outside (out) NPs. After adding the organic solution (Solution II) of $40 \%(\mathrm{w} / \mathrm{v})$ PLGA with cationic lipid (DOTAP or DC-Chol), the water-in-oil (W/O) emulsion was sonicated at output $4(50 \mathrm{~W})$ for 30 seconds (ultrasonic probe, Sonic \& Materials Inc., Danbury, CT, USA). Then it was transferred to an aqueous buffer (Solution III) containing $0.5 \%$ PVA and sonicated for $15 \mathrm{~min}$ at $30 \%$ amplitude. The resultant water-in-oil-in-water $(\mathrm{W} / \mathrm{O} / \mathrm{W})$ emulsion was stirred for $18 \mathrm{hrs}$ at room temperature with a magnetic stirrer until all of the organic solvent had evaporated. The NPs were collected by centrifugation at 35,000 rpm for 20 minutes at $10^{\circ} \mathrm{C}$ (Beckman Coulter-Optima L-100 XP Ultra Centrifuge, Fullerton, CA, USA), washed four times with TE buffer, and freeze dried at $-20^{\circ} \mathrm{C}$ for $48 \mathrm{hrs}$. The pLuc DNA was adsorbed to NPs for preparation of (out or both) NPs by overnight incubation at $4{ }^{\circ} \mathrm{C}$ using the concentrations shown in Tables 1 and 2.

\section{Table 1 Composition of nanoparticles complexed with DNA on the surface (out)}

\begin{tabular}{ccccc}
\hline Formulation & \multicolumn{2}{c}{ Cationic Particles } & DNA & Protamine Sulphate \\
\hline A1 (out) & DOTAP (A) & $10 \mathrm{mg}$ & $250 \mu \mathrm{g}$ & $150 \mu \mathrm{g}$ \\
B1 (out) & DC-Chol (B) & $10 \mathrm{mg}$ & $250 \mu \mathrm{g}$ & $150 \mu \mathrm{g}$ \\
\hline
\end{tabular}

A: PLGA/DOTAP-NPs B: PLGA/DC-Chol-NPs 
Table 2 Composition of NPs with DNA encapsulated (in) or adsorbed and encapsulated (both)

\begin{tabular}{|c|c|c|c|c|c|c|c|c|}
\hline \multirow{3}{*}{\multicolumn{2}{|c|}{ Formulation }} & \multicolumn{5}{|c|}{ Solutions } & \multicolumn{2}{|c|}{$\begin{array}{c}\text { NP Surface } \\
\text { Modifications (out) }\end{array}$} \\
\hline & & \multicolumn{2}{|c|}{$\mathrm{I}$} & \multicolumn{2}{|r|}{ II } & \multirow{2}{*}{$\frac{\text { III }}{\text { Buffer }}$} & \multirow[b]{2}{*}{ DNA } & \multirow[b]{2}{*}{ PS } \\
\hline & & PS & DNA & PLGA & Lipid & & & \\
\hline $\bar{C}$ & (in) & $450 \mu \mathrm{g}$ & $750 \mu \mathrm{g}$ & $30 \mathrm{mg}$ & 6.5 mg (DO) & $6 \mathrm{ml}$ & -—— & -——- \\
\hline D1 & (in) & $450 \mu \mathrm{g}$ & $750 \mu \mathrm{g}$ & $30 \mathrm{mg}$ & 6.5 mg (DC) & $6 \mathrm{ml}$ & - - - & -——- \\
\hline E1 & (both) & $112 \mu \mathrm{g}$ & $187 \mu \mathrm{g}$ & $15 \mathrm{mg}$ & 3.25 mg (DO) & $3 \mathrm{ml}$ & $187 \mu g$ & $112 \mu \mathrm{g}$ \\
\hline $\mathrm{F} 1$ & (both) & $112 \mu \mathrm{g}$ & $187 \mu \mathrm{g}$ & $15 \mathrm{mg}$ & 3.25 mg (DC) & $3 \mathrm{ml}$ & $187 \mu g$ & $112 \mu \mathrm{g}$ \\
\hline
\end{tabular}

PS: Protamine Sulphate DO: DOTAP DC: DC-Chol Buffer: $0.5 \%$ of PVA in Buffer

Particle Size, Zeta potential and Morphology of Nanoparticles

Particle size distribution and Zeta Potential were determined by a Delsa ${ }^{\mathrm{sm}}$ Nano C Zeta Potential and Submicron Particle Size Analyzer (Beckman Coulter Inc., Fullerton, CA, USA), using photon correlation spectroscopy (PCS). In this technique, the particle sizes are determined by measuring the rate of fluctuations in laser (30 mW dual laser) light intensity scattered by particles as they diffuse through a fluid. The NPs $(0.5 \mathrm{mg})$ dispersed in deionized water were added to a cell holder and counting was performed (70 accumulation times). Each experiment was performed in triplicate. The particle zeta potentials are determined by measuring the electrophoretic movement of charged particles under an applied electric field. The Delsa instrument used a zeta

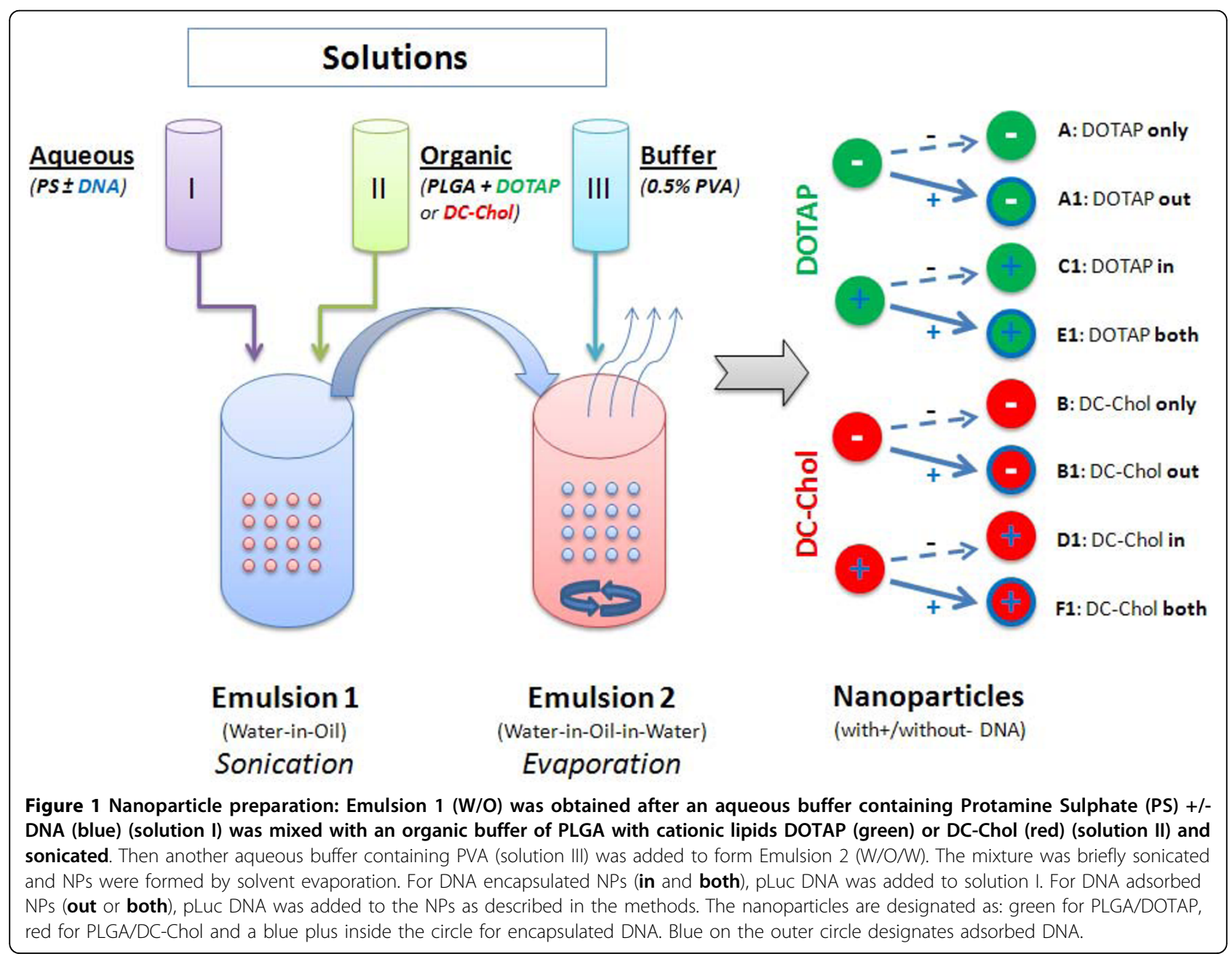


potential module equipped with a $35 \mathrm{~mW}$ two laser diode $(658 \mathrm{~nm})$. Scattered light was detected at a 90 angle and a temperature of $25^{\circ} \mathrm{C}$. About $1.6 \mathrm{ml}$ of a suspension of charged particles in water was used for the measurements. Zeta potential values (Tables 3 and 4) were calculated from measured velocities using the Smoluchowski equation.

The shape and surface morphology (smooth versus porous structure) of the nanoparticles were investigated using a scanning electron microscope (SEM) (S-4800N, Tokyo, Japan). Nanoparticles suspended in deionized water were freeze-dried. The dried nanoparticles were mounted on metal stubs with double sided tape and coated with a thin gold layer using an ion coater (K550X, EMITECH, Kent, UK).

\section{Quality Control for DNA Location on Nanoparticles}

We used measurement of luciferase activity for transgene expression, as the most sensitive assay to assign DNA location (out, in or both) on the different NP/DNA complexes. The six NPs were each suspended in water, treated with DNase I (Fermentas, Glen Burnie, MD) at $37^{\circ} \mathrm{C}$ for $30 \mathrm{~min}$, washed and delivered to 293 cells. Specifically, $16 \mu \mathrm{g}$ NPs (with or without DNase I treatment) were added to $10^{5}$ cells in 48 well plates for 48 hours and luciferase activity was measured as seen in Figure 2. We had previously tried unsuccessfully, to measure residual DNA by location on the NP/DNA complexes, using DNA concentration (OD at $260 \mathrm{~nm}$ ) or agarose gel electrophoresis before and after DNase I digestion.

\section{Evaluation of NP/DNA Complex Uptake in vitro by Cells} For dose responses assays, 293 cells were seeded onto 48 well plates at a density of $10^{5}$ cells per well in $1 \mathrm{ml}$

Table 3 Physical properties of PLGA cationic particles

\begin{tabular}{llcccc}
\hline \multirow{2}{*}{ Formulation } & \multicolumn{3}{c}{ Particle Size (nm) } & Zeta Potential (mv) \\
\cline { 3 - 5 } & & $\mathbf{d ~ ( 0 . 1 )}$ & $\mathbf{d ~ ( 0 . 5 )}$ & $\mathbf{d ~ ( 0 . 9 )}$ & \\
\hline A & PLGA/DOTAP & 95 & 218 & 425 & $52.64 \pm 1.17$ \\
B & PLGA/DC-Chol & 86 & 210 & 523 & $41.67 \pm 2.55$ \\
\hline
\end{tabular}

The mean size and distribution for different NPs are indicated; $d(0.1), d(0.5), d$ (0.9) means that less than $10 \%, 50 \%, 90 \%$ of the NPs respectively, are distributed around the particle sizes indicated

Table 4 Zeta potential of nanoparticle DNA complexes

\begin{tabular}{lllc}
\hline \multicolumn{3}{c}{ Formulation } & Zeta Potential (mv) \\
\hline A1 & DOTAP & (out) & $06.86 \pm 0.72$ \\
B1 & DC-Chol & (out) & $05.83 \pm 0.24$ \\
C1 & DOTAP & (in) & $31.95 \pm 0.99$ \\
D1 & DC-Chol & (in) & $14.84 \pm 0.11$ \\
E1 & DOTAP & (both) & $16.40 \pm 0.27$ \\
F1 & DC-Chol & (both) & $06.46 \pm 0.07$ \\
\hline
\end{tabular}

DOTAP: PLGA/DOTAP DC-Chol: PLGA/DC-Chol
DMEM (Invitrogen, Carisbad, CA) containing 10\% FBS. Incubation of cells was for $24 \mathrm{hr}$ at $37^{\circ} \mathrm{C}$ in a $5 \% \mathrm{CO}_{2}$ incubator. Each of the six different NPs in $50 \mu \mathrm{l}$ PBS and containing pLuc DNA was added at concentrations of $164 \mathrm{ng}$ to $100 \mu \mathrm{g}$ (in 2 to 2.5 fold-stepwise intervals) to separate wells. After $48 \mathrm{hrs}$ incubation, luciferase was assayed using a kit from Promega. DNA with Lip2000 was the positive control (PC) and DNA only was the negative control (NC).

Regression analysis and determination of the declination angles for DNA uptake of NPs by 293 cells was performed using the trend line program from a Microsoft Excel 2007 software statistical package. Cells were passaged at $10^{5}$ cells per $\mathrm{ml}$ in a T25 flask containing 5 ml DMEM with $10 \%$ FBS. After $24 \mathrm{hr}$, each of the six NPs containing pLuc DNA was added at $40 \mu \mathrm{g}$ and culturing was maintained for up to 4 weeks. At 3 or 4 day intervals, cell density was adjusted to $10^{5}$ cells per ml by adding fresh medium. DNA activity was measured by the luciferase assay.

\section{Results and Discussion}

\section{Characterization of hybrid nanoparticle/DNA complexes}

PLGA based NPs prepared by the solvent evaporation method (Figure 1), with either DOTAP or DC-Chol showed a similar particle size distribution (Figure 3). From the representative size distribution diagrams, it can be seen that in both formulations $70 \%$ of particles were in the range of $100-400 \mathrm{~nm}$. NPs formulated, either with DOTAP or DC-Chol, exhibit a uniform spherical shape with smooth surface as seen by scanning electron microscopy. The particle size distributions and zeta potentials are described in Table 3. Initially, PLGA NPs with PVA, a most commonly used surfactant or stabilizer, have a negative surface charge because of physical entrapment of liquid within the surface layer of the polymer [38]. In our formulations, after addition of cationic lipids (DOTAP and DCChol) an overall positive charge is imparted to the NP surface. The PLGA/DOTAP and PLGA/DC-Chol NPs also were complexed with luciferase gene plasmid DNA pLuc (pGL4.75), at the concentrations described (Table 1,2). Although the zeta potential is varied in all formulations, it is still positive in all cases. The lower positive zeta potentials of adsorbed NPs (out and both) may possibly be due to the nullifying effects of negative charge on DNA versus the positive charge of cationic lipid on the surface of these NPs, compared to encapsulated NPs (in) (Table 4). Previous studies with such cationic lipid/DNA NP complexes have shown that they are stable [34] and efficiently taken up by tissue culture cells [35,39]. In this study we have focused on delivery of such NPs to 293 and other cells. 


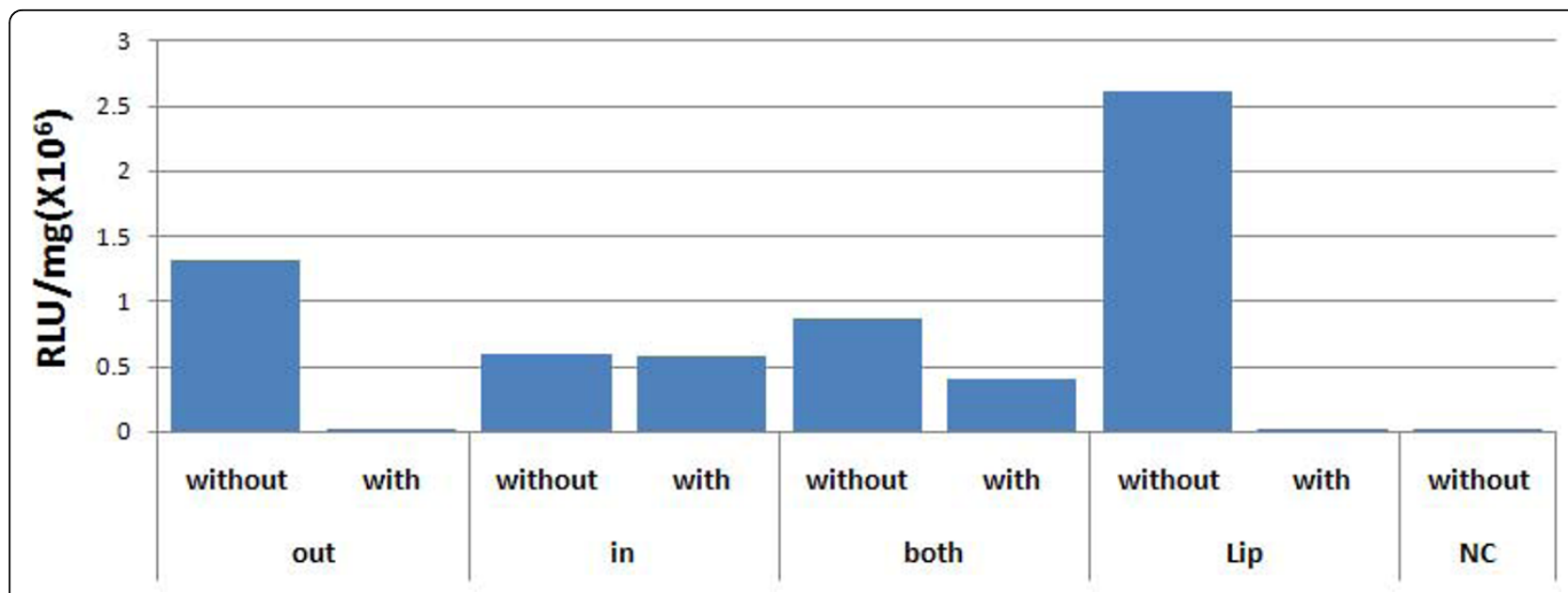

Figure 2 Quality control for pLuc DNA adsorbed to either surface NPs (out and both) or encapsulated NPs (in and both). The NP/DNA complexes were treated with or without DNase I and delivered to 293 cells for 48 hours. Lipofectamine 2000 with pLuc DNA was a positive control (Lip) and untreated 293 cells was the negative control (NC). The assay measures luciferase activity.
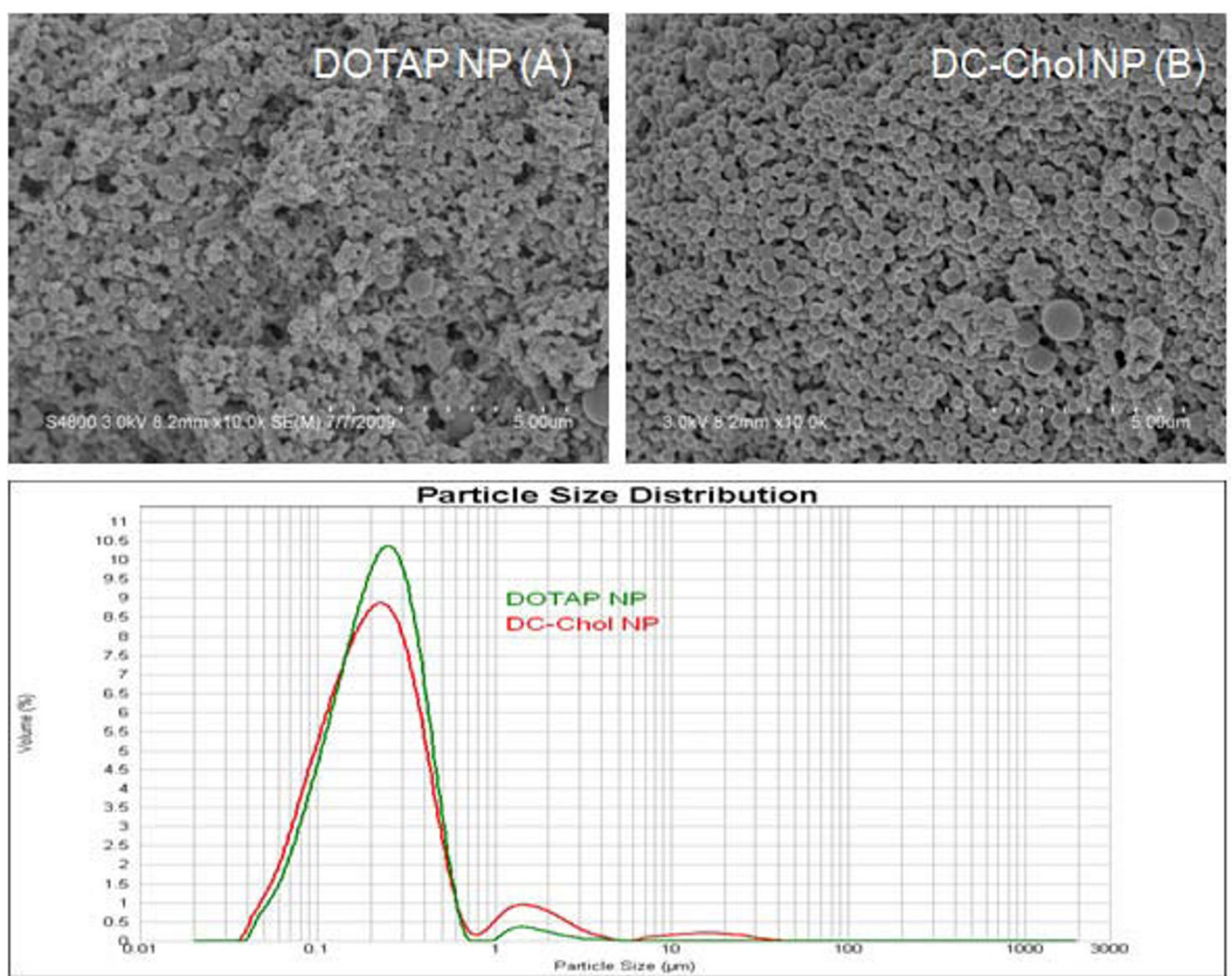

Figure 3 SEM photomicrograph of PLGA/DOTAP and PLGA/DC-Chol nanoparticles (top). The corresponding particle size distribution for PLGA/DOTAP nanoparticles (green) and PLGA/DC-Chol nanoparticles (red) is on the bottom. 


\section{Optimization of NP DNA binding conditions}

We determined the optimal conditions for binding the maximal amount of DNA to the PLGA hybrid NPs. The two types, DOTAP (A) or DC-Chol (B) hybrid NPs, were complexed with luciferase gene plasmid DNA at a $\mathrm{w} / \mathrm{w}$ ratio of $10 / 1$ and held at $4^{\circ} \mathrm{C}$, room temperature $\left(22^{\circ} \mathrm{C}\right)$ or $50^{\circ} \mathrm{C}$ for $1,2,3,4$ hours, as well as overnight. Both types gave similar results, so we will describe specific findings for DOTAP/DNA NPs (out). After 3 hours at $4^{\circ} \mathrm{C}$ or $22^{\circ} \mathrm{C}$ these NPs have a similar, high level of DNA binding activity relative to those held at $50^{\circ} \mathrm{C} .100$ $\mu \mathrm{g}$ of such NP/DNA complexes formed at $4^{\circ} \mathrm{C}$ or room temperature were then transferred for uptake to $10^{5} 293$ cells in $1 \mathrm{ml}$ and incubated for 1 day. About a 23\% increase in DNA binding was observed at $4{ }^{\circ} \mathrm{C}$. The maximal amount of DNA that could tightly bind to the NPs at $4^{\circ} \mathrm{C}$ was then determined. For this, NP/DNA (w/w) ratios of $10 / 1$ to $50 / 1$ were incubated overnight at $4^{\circ} \mathrm{C}$. Then the NPs were pelleted and the supernatant was collected. DNA measurements were made both for the NP/DNA complexes and free DNA using $1 \mathrm{mg}$ of NP complexed with $100 \mu \mathrm{g}, 50 \mu \mathrm{g}, 40 \mu \mathrm{g}$ and $20 \mu \mathrm{g}$ of DNA. The amount of free DNA was highest at the 10/1 ratio and lowest at the 50/1 ratio; however all levels showed that $\geq 95 \%$ of DNA was bound to the NP. Based on these findings, our experiments utilized NPs at a ratio of 20-30 $\mu \mathrm{g}$ DNA/1 mg NP, in order to avoid competition with free DNA.

\section{Localization of DNA in the nanoparticles/DNA complexes} The six NP/DNA complexes were suspended in water at $10 \mathrm{mg} / \mathrm{ml}$. In order to verify DNA location on the outside or inside of the NP complexes respectively, we used the following approach to determine sensitivity to DNase I. NP/DNA complexes were treated with DNase I and delivered to 293 cells. Expression of residual DNA was assigned by measuring luciferase activity after 48 hours. We note in Figure 2 that those NP/ DNA complexes where DNA was adsorbed on outer surfaces (out and both) were able to be cleaved by DNase I. Thus no expression was detected for out, but about $50 \%$ expression was detected for both. As expected, no difference was seen for NPs with encapsulated DNA (in) (Figure 2).

\section{Optimization of NP/DNA complex delivery conditions to 293 cells}

We compared the efficiency of DNA delivery to 293 cells by the six NP/DNA complexes vs. a Lip2000/DNA mixture. Lipofectamine 2000 is a cationic lipid widely used to transfect plasmid and other DNA into a variety of mammalian cells. Invitrogen reports [40] that 293 cells transfected with pCMV- $\beta$ gal DNA exhibited a high transfection efficiency (99\%) and 100\% cell viability at 24 hours post transfection. PLGA/DOTAP or PLGA/ DC-Chol NPs with the composition of pLuc DNA seen in Tables 1 and 2 were formulated as in Figure 1, and all six were used at a concentration of $25 \mu \mathrm{g}$ DNA/1 mg NP. NPs were added to $10^{5}$ cells at 2 to 2.5 fold increasing concentrations starting at $164 \mathrm{ng}$ and going to $100 \mu$ g for 2 days (Figure 4). Based on the $\mathrm{R}^{2}$ value of the straight line seen in Figure 5 for the three DOTAP NP/DNA complexes, the transfection efficiency achieved is high and similar to that for Lip2000/DNA complexes.

Although Lipofectamine 2000 appears effective at lower concentrations of plasmid DNA (100 pg to 100 $\mathrm{ng}$ ), it has the disadvantage of toxicity, as noted in the introduction and thus would have limited applicability in vivo. Specifically, high cytotoxicity in renal and arterial tissue-based studies [41,42], as well as in animal applications $[43,44]$ have been reported. Hybrid NPs in contrast, are safe in cell and animal studies $[41,45]$. Further, from Figures 4 and 5 we note that NPs are best used at concentrations of 16-40 $\mu \mathrm{g} \mathrm{NPs} / \mathrm{ml}$ with 293 cells; NP levels $\geq 100 \mu \mathrm{g} / \mathrm{ml}$ are cytotoxic (data not shown). The DNA binding experiment seen in Figure 5 was repeated with DC-Chol NPs and gave a similar result. The relative transfection efficiency of pLuc DNA calculated from these experiments show that DOTAP or DC-Chol NPs are nearly as efficient as Lip2000 in delivering DNA to 293 cells; however, when compared to free DNA, NPs have a 500-600 fold higher transmission efficiency. In conclusion, we find that after 2 days of NP/DNA complex delivery to 293 cells (Figure 4), "Out" NPs shows a higher luciferase expression than NPs with only inside DNA (in) and luciferase expression is intermediate for "Both" NPs. This suggests that outside DNA exhibits an initial high expression due to rapid release of bound DNA. On the other hand, DNA encapsulated NPs (in) are slower to release DNA and are probably affected by biodegradation of the NPs within cells.

\section{Study of gene delivery with hybrid nanoparticle/DNA complexes using other cell lines}

The optimal condition for DNA gene delivery to 293 cells was shown in Figures 4 and 5, and we found that all six NP/DNA complexes showed a high efficiency of gene transfection. We also were interested in checking transfection with other cell lines and found that two adherent prostate cell lines (PC-3, LNcap) gave the same high efficiency for the six different hybrid NP/ DNA complexes, again compared to Lip2000 (data not shown). Interestingly, when non-adherent MOLT-4 cells were used, only a high transfection efficiency was found with the NP/DNA complexes and not Lip2000 (data not shown). 


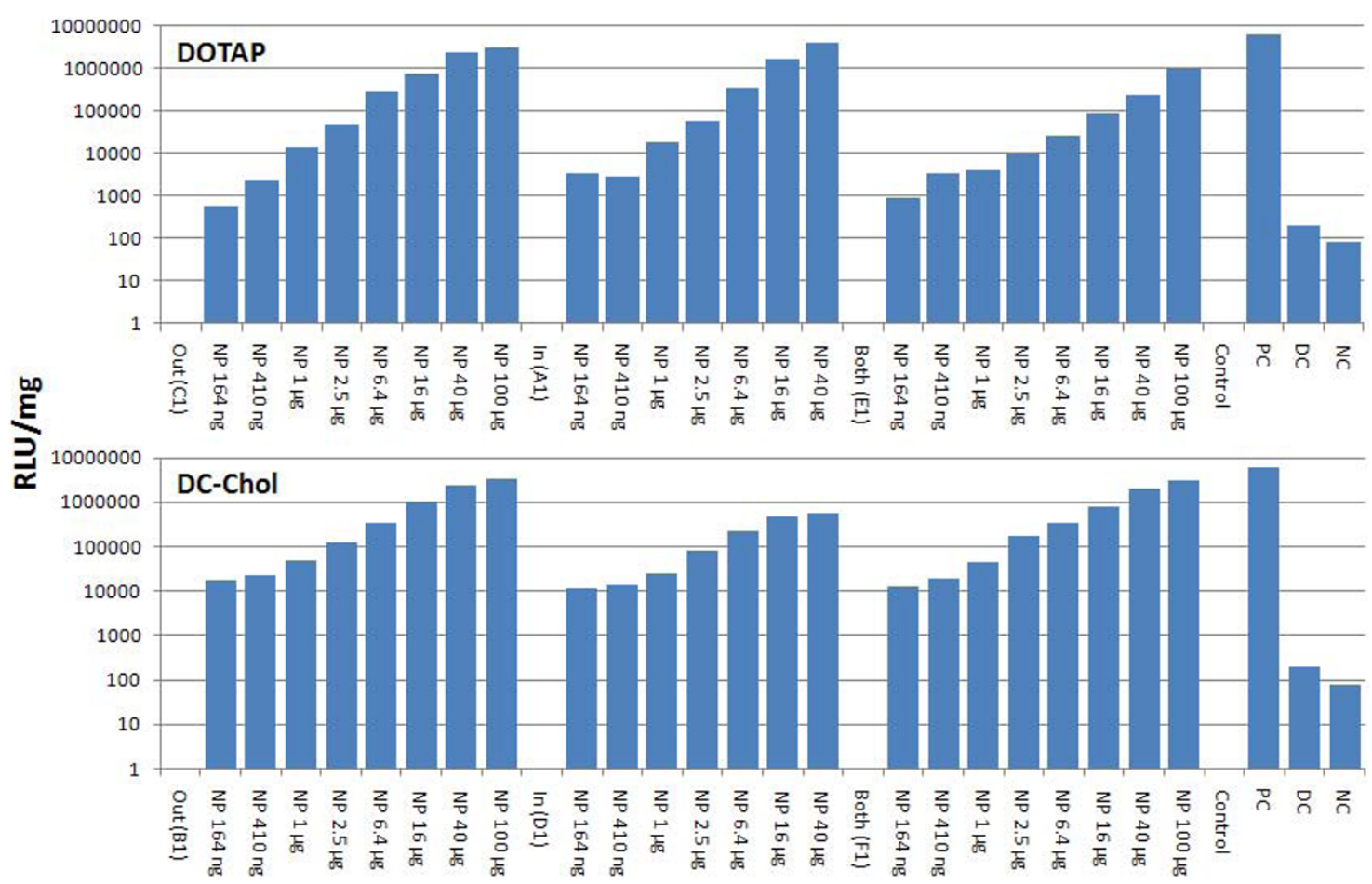

Figure 4 Dose/response bar graphs showing efficiency of DNA delivery to 293 cells after 48 hours incubation for three classes of NPs made from two type of cationic lipid; DOTAP (top) and DC-Chol (bottom). NP/DNA complexes were added at concentrations from $164 \mathrm{ng}$ to $100 \mu \mathrm{g}$ in 2.5 fold-stepwise intervals. Positive control (PC) is Lipofectamine 2000 with $100 \mathrm{ng}$ DNA; DNA control (DC) uses $10 \mu \mathrm{g}$ DNA alone; Negative control (NC) is 293 cells only and no particles, lipofectamine or DNA.

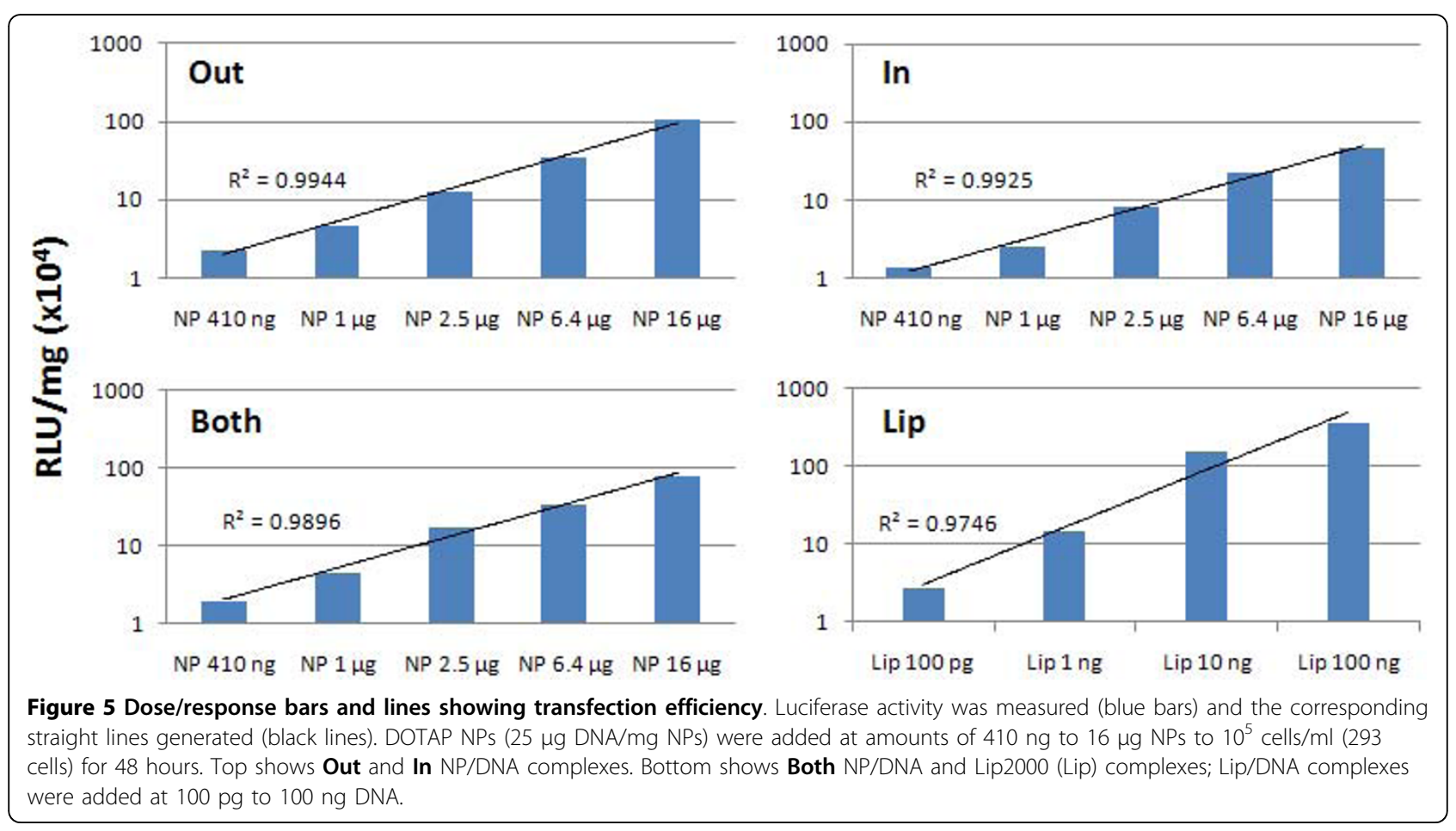


Degradation of NP/DNA complexes delivered to 293 cells For these experiments, we freshly prepared the six NP/ DNA complexes, using a NP/DNA (w/w) ratio of 40/1 (Figure 1). Such complexes bound DNA at a level of $96 \%$ to $99 \%$. They were added to 293 cells for 3 days and incubated at $37^{\circ} \mathrm{C}$ for about 4 weeks. Cell passages were done at 3 to 4 day intervals. Samples were removed at these times and the level of luciferase DNA was measured. The results are shown in Figure 6 with a positive control using Lipofectamine (Lip). The top figure presents the data in a graph format, while the middle and bottom provide the data as straight lines. These results represent the release profile of DNA from the NP/DNA complexes within 293 cells, over time. Regression analysis was performed and lines were drawn of the data points taken for the 4 week period. DC-Chol NPs containing externally bound DNA (out) (bottom graph) exhibited a large initial uptake followed by a steep decay of pLuc DNA, similar to Lipofectamine. However with DOTAP (middle graph), externally bound DNA NPs (out) exhibited a diminished slope of DNA decay relative to Lipofectamine. DOTAP NPs

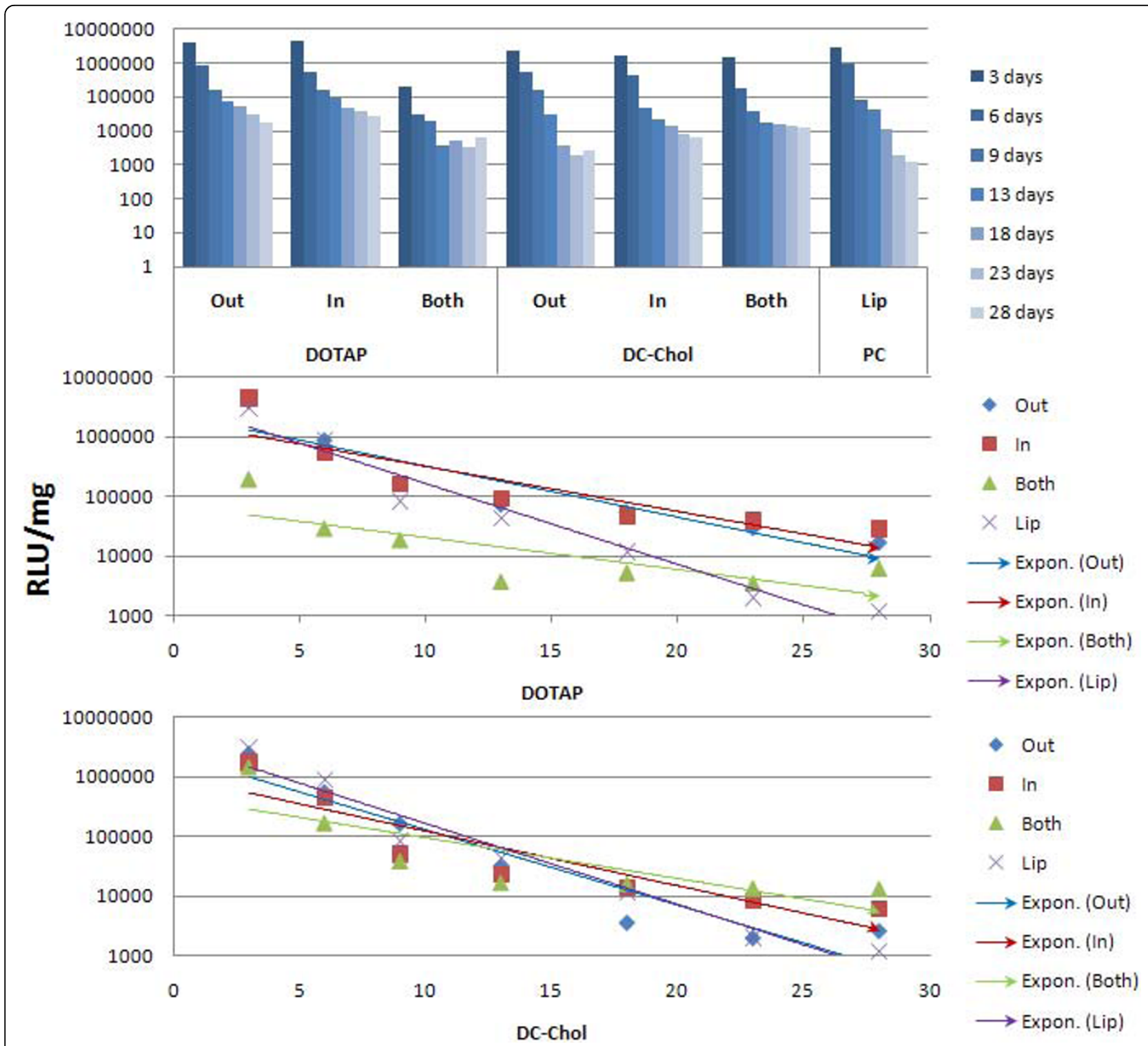

Figure 6 Degradation analysis for DNA delivery to 293 cells by six different nanoparticle/DNA complexes over a four week period. Two NP/cationic lipid mixtures (PLGA/DOTAP and PLGA/DC-Chol) and three classes of NP/DNA complexes (out, in and both) were used. Lip (Lip2000/DNA mixture) was a positive control. Top columns show luciferase activity at 3 or 4 day intervals for 4 weeks. Middle graph is (DOTAP) and bottom graph (DC-Chol) NPs. Regression analysis gave straight lines (blue for out, red for in and green for both) for nanoparticles and Lip (purple). 
Table 5 Angle of regression line declination* over a four week period for six nanoparticle preparations

\begin{tabular}{ccccccc}
\hline Experiment & \multicolumn{3}{c}{ DOTAP } & \multicolumn{3}{c}{ DC-Chol } \\
& out & in & both & out & in & both \\
\hline$\# 1$ & $35.5^{\circ}$ & $32.3^{\circ}$ & $25.3^{\circ}$ & $46.8^{\circ}$ & $35.9^{\circ}$ & $29.5^{\circ}$ \\
$\# 2$ & $30.1^{\circ}$ & $28.1^{\circ}$ & $17.4^{\circ}$ & $39.2^{\circ}$ & $32.0^{\circ}$ & $23.7^{\circ}$ \\
$\# 3$ & $42.3^{\circ}$ & $36.5^{\circ}$ & $28.7^{\circ}$ & $54.5^{\circ}$ & $36.5^{\circ}$ & $34.6^{\circ}$ \\
\hline Average & $36.0^{\circ}$ & $32.3^{\circ}$ & $23.8^{\circ}$ & $46.8^{\circ}$ & $34.8^{\circ}$ & $29.3^{\circ}$ \\
\hline
\end{tabular}

*Angle is in degrees and reflects pLuc DNA degradation over time in 293 cells

(middle graph) and DC-Chol NPs (bottom graph) with bound and encapsulated DNA (both) also led to a large initial uptake, but it was followed by sustained DNA release over a longer time. This is correlated with a lower angle of declination of the regression line than Lip (average angle of $23.8^{\circ}$ for DOTAP and $29.3^{\circ}$ for DC-Chol) (Table 5). NPs with only encapsulated DNA (in) showed an intermediate level of DNA degradation. Since all assays started with the same number of cells, this different decline in luciferase activity with different NPs is not likely to be a cell dilution problem. In summary, the "Lip" and "Out" NP complexes have similar profiles (steep slope) because both have outside bound DNA and the expression assay in 293 cells reflects the rapid release of such bound DNA. On the other hand, "In" and "Both" have longer retention profiles, indicating that this expression assay is affected by biodegradation in time, of encapsulated NP/DNA complexes within cells. However, our results show that the "Both" NP/DNA complexes, which have DNA both outside and inside show a higher level of luciferase activity after four weeks than the "In" NP/DNA complexes. This may be because the former NPs with DNA on the outside can stabilize the surface charge and allow for a longer retention time within 293 cells. These findings are important for the future design of vaccines using NP/DNA complexes. Thus, when an initial strong gene delivery response over a short time is required, as in "priming" for an antibody in animals, it appears that NP complexes with adsorbed DNA (out) are best used. However, for a response where one wants a longer time of gene delivery, as in a "booster" inoculation, the adsorbed/encapsulated DNA complexes (both) are best used. It should be noted with NPs that there is always the potential for an inflammatory response as with gene delivery systems, but in both cases this is usually dependent on immune response to the transgene product.

\section{Conclusion}

Nanoparticles provide a better vector than DNA alone for luciferase gene delivery (500-600 times more efficient). A dose response curve for gene delivery of six different NP/DNA complexes to 293 cells has been generated; optimal delivery conditions occur for $10^{5}$ cells over a range of $500 \mathrm{ng}-10 \mu \mathrm{g}$ of NPs containing 20-30 $\mu \mathrm{g}$ DNA per $1 \mathrm{mg}$ of NPs. NPs with externally bound DNA (out) led to a steep slope on lines drawn from regression analysis, while NPs with both adsorbed and encapsulated DNA (both) exhibited a longer retention time. This offers the potential of using hybrid NPs with adsorbed DNA (out) for "priming" in animal immunization studies, while DNA adsorbed/encapsulated NPs (both) are optimal for "booster" immunization.

\section{Acknowledgements}

This work was supported, in part, by the Louisiana Vaccine Center and the South Louisiana Institute for Infectious Disease Research sponsored by the Louisiana Board of Regents and LEQSF(2007-12)-ENH-PKSFI-PRS-02.

\section{Author details}

'Department of Microbiology Immunology and Parasitology, Louisiana State University Health Sciences Center, New Orleans, Louisiana 70112, USA. ${ }^{2}$ College of Pharmacy, Xavier University of Louisiana, New Orleans, Louisiana 70125, USA. ${ }^{3}$ Guangdong Food and Drug Vocational College, Guang Zhou, Guangdong 510520, PR China.

\section{Authors' contributions}

QZ carried out design and performed study, data analysis and drafting of the manuscript. TKM directed, while DMDC and SP carried out NP formulation and characterization such as particle size, zeta potential and morphology of nanoparticles. HW consulted and participated in the design of the study. XY carried out the Luciferase assay in evaluation of NPs and prepared cells. RBL was involved with the design, coordination, data analysis and drafting of the manuscript through its many revisions. All authors read and approved the final manuscript.

\section{Competing interests}

The authors declare that they have no competing interests.

Received: 24 November 2009

Accepted: 24 February 2010 Published: 24 February 2010

\section{References}

1. Maguire AM, Simonelli F, Pierce EA, Pugh EN Jr, Mingozzi F, Bennicelli J, Banfi S, Marshall KA, Testa F, Surace EM, Rossi S, Lyubarsky A, Arruda VR, Konkle B, Stone E, Sun J, Jacobs J, Dell'Osso L, Hertle R, Ma JX, Redmond TM, Zhu X, Hauck B, Zelenaia O, Shindler KS, Maguire MG, Wright JF, Volpe NJ, McDonnell JW, Auricchio A, et al: Safety and efficacy of gene transfer for Leber's congenital amaurosis. N Engl J Med 2008, 358:2240-2248

2. Stewart DJ, Hilton JD, Arnold JM, Gregoire J, Rivard A, Archer SL, Charbonneau F, Cohen E, Curtis M, Buller CE, Mendelsohn FO, Dib N, Page P, Ducas J, Plante S, Sullivan J, Macko J, Rasmussen C, Kessler PD, Rasmussen HS: Angiogenic gene therapy in patients with nonrevascularizable ischemic heart disease: a phase 2 randomized, controlled trial of AdVEGF(121) (AdVEGF121) versus maximum medical treatment. Gene Ther 2006, 13:1503-1511.

3. Nikol S, Engelmann MG, Pelisek J, Fuchs A, Golda A, Shimizu M, Mekkaoui C, Rolland PH: Local perivascular application of low amounts of a plasmid encoding for vascular endothelial growth factor (VEGF165) is efficient for therapeutic angiogenesis in pigs. Acta Physiol Scand 2002, 176:151-159

4. Li C, Hirsch M, DiPrimio N, Asokan A, Goudy K, Tisch R, Samulski RJ: Cytotoxic-T-lymphocyte-mediated elimination of target cells transduced with engineered adeno-associated virus type 2 vector in vivo. J Virol 2009, 83:6817-6824.

5. Mulligan RC: The basic science of gene therapy. Science 1993, 260:926-932. 
6. Miyake K, Suzuki N, Matsuoka H, Tohyama T, Shimada T: Stable integration of human immunodeficiency virus-based retroviral vectors into the chromosomes of nondividing cells. Hum Gene Ther 1998, 9:467-475.

7. Marshall E: Gene therapy. What to do when clear success comes with an unclear risk?. Science 2002, 298:510-511.

8. Ott MG, Schmidt M, Schwarzwaelder K, Stein S, Siler U, Koehl U, Glimm H, Kuhlcke K, Schilz A, Kunkel H, Naundorf S, Brinkmann A, Deichmann A, Fischer M, Ball C, Pilz I, Dunbar C, Du Y, Jenkins NA, Copeland NG, Luthi U, Hassan M, Thrasher AJ, Hoelzer D, von Kalle C, Seger R, Grez M: Correction of X-linked chronic granulomatous disease by gene therapy, augmented by insertional activation of MDS1-EVI1, PRDM16 or SETBP1. Nat Med 2006, 12:401-409.

9. von Kalle C, Fehse B, Layh-Schmitt G, Schmidt M, Kelly P, Baum C: Stem cell clonality and genotoxicity in hematopoietic cells: gene activation side effects should be avoidable. Semin Hematol 2004, 41:303-318.

10. Baum C, Dullmann J, Li Z, Fehse B, Meyer J, Williams DA, von Kalle C: Side effects of retroviral gene transfer into hematopoietic stem cells. Blood 2003, 101:2099-2114.

11. Cohen J: AIDS research. Did Merck's failed HIV vaccine cause harm?. Science 2007, 318:1048-1049.

12. Tal J: Adeno-associated virus-based vectors in gene therapy. J Biomed Sci 2000, 7:279-291.

13. Campos SK, Barry MA: Current advances and future challenges in Adenoviral vector biology and targeting. Curr Gene Ther 2007, 7:189-204.

14. Amalfitano A: Next-generation adenoviral vectors: new and improved. Gene Ther 1999, 6:1643-1645.

15. Scallan CD, Liu T, Parker AE, Patarroyo-White $S L$, Chen H, Jiang $H$, Vargas J, Nagy D, Powell SK, Wright JF, Sarkar R, Kazazian HH, McClelland A, Couto LB: Phenotypic correction of a mouse model of hemophilia $A$ using AAV2 vectors encoding the heavy and light chains of FVIII. Blood 2003, 102:3919-3926.

16. Hartig PC, Hunter ES: Gene delivery to the neurulating embryo during culture. Teratology 1998, 58:103-112.

17. Mintzer MA, Simanek EE: Nonviral vectors for gene delivery. Chem Rev 2009, 109:259-302.

18. Anwer K: Formulations for DNA delivery via electroporation in vivo. Methods Mol Biol 2008, 423:77-89.

19. Kasuya T, Kuroda S: Nanoparticles for human liver-specific drug and gene delivery systems: in vitro and in vivo advances. Expert Opin Drug Deliv 2009, 6:39-52.

20. Konig Merediz SA, Zhang EP, Wittig B, Hoffmann F: Ballistic transfer of minimalistic immunologically defined expression constructs for IL4 and CTLA4 into the corneal epithelium in mice after orthotopic corneal allograft transplantation. Graefes Arch Clin Exp Ophthalmol 2000, 238:701-707.

21. Reed SD, Li S: Electroporation Advances in Large Animals. Curr Gene Ther 2009, 9:316-326

22. Mir LM: Nucleic Acids Electrotransfer-Based Gene Therapy (Electrogenetherapy): Past, Current, and Future. Mol Biotechnol 2009, 43:167-176.

23. Wells DJ: Gene therapy progress and prospects: electroporation and other physical methods. Gene Ther 2004, 11:1363-1369.

24. Liu Y, Liggitt D, Zhong W, Tu G, Gaensler K, Debs R: Cationic liposomemediated intravenous gene delivery. J Biol Chem 1995, 270:24864-24870

25. Gao X, Huang L: Cationic liposome-mediated gene transfer. Gene Ther 1995, 2:710-722.

26. Canonico AE, Plitman JD, Conary JT, Meyrick BO, Brigham KL: No lung toxicity after repeated aerosol or intravenous delivery of plasmidcationic liposome complexes. J Appl Physiol 1994, 77:415-419.

27. Porteous DJ, Dorin JR, McLachlan G, Davidson-Smith H, Davidson $H$, Stevenson BJ, Carothers AD, Wallace WA, Moralee S, Hoenes C, Kallmeyer G, Michaelis U, Naujoks K, Ho LP, Samways JM, Imrie M, Greening AP, Innes JA: Evidence for safety and efficacy of DOTAP cationic liposome mediated CFTR gene transfer to the nasal epithelium of patients with cystic fibrosis. Gene Ther 1997, 4:210-218.

28. Nchinda G, Zschornig O, Uberla K: Increased non-viral gene transfer levels in mice by concentration of cationic lipid DNA complexes formed under optimized conditions. J Gene Med 2003, 5:712-722.

29. Cemazar M, Sersa G, Wilson J, Tozer GM, Hart SL, Grosel A, Dachs GU: Effective gene transfer to solid tumors using different nonviral gene delivery techniques: electroporation, liposomes, and integrin-targeted vector. Cancer Gene Ther 2002, 9:399-406.

30. Huang YC, Riddle K, Rice KG, Mooney DJ: Long-term in vivo gene expression via delivery of PEI-DNA condensates from porous polymer scaffolds. Hum Gene Ther 2005, 16:609-617.

31. Nguyen DN, Raghavan SS, Tashima LM, Lin EC, Fredette SJ, Langer RS, Wang C: Enhancement of poly(orthoester) microspheres for DNA vaccine delivery by blending with poly(ethylenimine). Biomaterials 2008, 29:2783-2793.

32. Benita S, Benoit JP, Puisieux F, Thies C: Characterization of drug-loaded poly(d, I-lactide) microspheres. J Pharm Sci 1984, 73:1721-1724.

33. Pamujula S, Graves RA, Moiseyev R, Bostanian LA, Kishore V, Mandal TK: Preparation of polylactide-co-glycolide and chitosan hybrid microcapsules of amifostine using coaxial ultrasonic atomizer with solvent evaporation. J Pharm Pharmacol 2008, 60:283-289.

34. Singh M, Briones $\mathrm{M}, \mathrm{Ott} \mathrm{G}, \mathrm{O}$ 'Hagan $\mathrm{D}$ : Cationic microparticles: A potent delivery system for DNA vaccines. Proc Natl Acad Sci USA 2000, 97:811-816.

35. Gvili K, Benny O, Danino D, Machluf M: Poly(D, L-lactide-co-glycolide acid) nanoparticles for DNA delivery: waiving preparation complexity and increasing efficiency. Biopolymers 2007, 85:379-391.

36. Diez $S$, Navarro G, de ICT: In vivo targeted gene delivery by cationic nanoparticles for treatment of hepatocellular carcinoma. $J$ Gene Med 2009, 11:38-45.

37. Shive MS, Anderson JM: Biodegradation and biocompatibility of PLA and PLGA microspheres. Adv Drug Deliv Rev 1997, 28:5-24.

38. Evora C, Soriano I, Rogers RA, Shakesheff KN, Hanes J, Langer R: Relating the phagocytosis of microparticles by alveolar macrophages to surface chemistry: the effect of 1,2-dipalmitoylphosphatidylcholine. J Control Release 1998, 51:143-152.

39. Oberl V, Zuhorn IS, Audouy S, Bakowsky U, Smisterova J, Engberts JBFN, Hoekstra D: Targeting of Drugs. Gregoriadis G, McCormack B (Series Editor) IOS PressGregoriadis G, McCormack B

40. Ohki EC, Tilkins ML, Ciccarone VC, Price PJ: Improving the transfection efficiency of post-mitotic neurons. J Neurosci Methods 2001, 112:95-99.

41. Bejjani RA, BenEzra D, Cohen H, Rieger J, Andrieu C, Jeanny JC, Gollomb G, Behar-Cohen FF: Nanoparticles for gene delivery to retinal pigment epithelial cells. Mol Vis 2005, 11:124-132.

42. Madry H, Reszka R, Bohlender J, Wagner J: Efficacy of cationic liposomemediated gene transfer to mesangial cells in vitro and in vivo. $J$ Mol Med 2001, 79:184-189.

43. Armeanu S, Pelisek J, Krausz E, Fuchs A, Groth D, Curth R, Keil O, Quilici J, Rolland PH, Reszka R, Nikol S: Optimization of nonviral gene transfer of vascular smooth muscle cells in vitro and in vivo. Mol Ther 2000, 1:366-375.

44. Gebhart CL, Kabanov AV: Evaluation of polyplexes as gene transfer agents. J Control Release 2001, 73:401-416.

45. Azarmi S, Lobenberg R, Roa WH, Tai S, Finlay WH: Formulation and in vivo evaluation of effervescent inhalable carrier particles for pulmonary delivery of nanoparticles. Drug Dev Ind Pharm 2008, 34:943-947.

\section{doi:10.1186/1477-3155-8-6}

Cite this article as: Zhong et al:: Optimization of DNA delivery by three classes of hybrid nanoparticle/DNA complexes. Journal of Nanobiotechnology 2010 8:6.

\section{Submit your next manuscript to BioMed Central and take full advantage of:}

- Convenient online submission

- Thorough peer review

- No space constraints or color figure charges

- Immediate publication on acceptance

- Inclusion in PubMed, CAS, Scopus and Google Scholar

- Research which is freely available for redistribution 